\title{
Induction and Staff Attitude towards Retention and Organizational Effectiveness
}

\author{
Odunayo Paul Salau ${ }^{1}$, Hezekiah Olubusayo Falola ${ }^{2}$ James Olalekan Akinbode ${ }^{3}$ \\ ${ }^{1,2}$ Department of Business Management, Covenant University, Ogun State \\ ${ }^{3}$ Business Administration Department, Federal Polytechnics Offa, Kwara State
}

\begin{abstract}
Organizations continuously find themselves assessing what resources or tools that can be used to educate their employees. This may be due to the fact that organizations do not have clear ethics which can be communicated to employees. Therefore, this study examined how knowledgeable staffs are about the meaning and benefits of induction. It examined the main attitudes of workers towards induction/orientation to work and how induction programmes motivate staff to be committed to the organizational effectiveness. Descriptive research method was adopted for this study using two hundred and seventy one (271) valid questionnaires which were completed by academic and non-academic staff of Olabisi Onabanjo University, Ago Iwoye, Ogun State Nigeria. The data collected were carefully analyzed using descriptive statistics to represent the raw data in a meaningful manner. The findings revealed that induction significantly influences staff attitude and behaviour towards organizational effectiveness. This means that well packaged induction programme will positively influence staff attitude. It was recommended that induction programmes should be reviewed and improved upon from time to time to earn employees loyalty and positive attitudes towards work
\end{abstract}

Keywords: Induction, Orientation, Effectiveness, Attitude, Values, Performance, Commitment

\section{Introduction}

Induction is the logical and the most important step in human resource management process. This process starts from the period where the new employee is taken round the offices, factory, and also introduced to the facilities/amenities available. Induction ensures a new employee is provided with information and assistance when commencing employment with an organization. Clearly outlining what the organization stands for and requires, reducing the risk of regulatory breaches and enabling employees to respond effectively to new responsibilities. Induction as the process of receiving employees when they begin work, introducing them to the company and their colleagues, and informing them of the activities, customs and traditions of the company Armstrong (1982). Ogunbameru (2004) opined that the objective of any induction process is to facilitate the transition of new employees into the working environment and enable them to respond effectively to new responsibilities. Armstrong (2003) explained that induction provides the opportunity to shape work related attitudes and enhance organizational commitment.

Attitudes, according to Kenrick, Neuberg \& Cialdini (2005) are favourable or unfavourable evaluations of particular person, people, objects, events or ideas. It is worthy to reinstate that it is only when staffs have been given proper induction about the organization structure, what the organization stand for, organizational goals and organizational ethics that managers can expect positive of favourable staff attitude. For instance, a new employee that does not know that eating in the office during official hours is bad, cannot be blamed for eating in the office or even in front of visitors.

Many organizations do not involve their new staff in induction, therefore, most of them are vulnerable during the first few weeks of employment and this might discourage the new employees and thus, organization stand the risk of turnover (Kearney, 2010, Snell, 2006). Meanwhile, induction of new staff is should centered on the practical knowledge, skills and competency of the new staff and clear cut understanding of the organizational culture, ethics and core values. Hendricks and Louw-Potgieter (2012). The survey became necessary to find out the impact of induction programme employees' attitude to work and intention to stay lon on the job. The significance of this work stemmed from its objectives is as follows:

i. Examine the effect of induction programme on the employees' attitudes and retention

ii. Evaluate the impact induction on employees' commitment and organizational effectiveness

iii. Analyze the effect of induction programme on employees satisfaction and intention to stay on the job

\section{Review Of Literature}

Induction/orientation has become one of the fundamental types of organizational training programmes (Klein \& Weaver, 2000). Several studies have indicated that many industrial organizations adopt different means of acclimatizing and introducing employees to their jobs and environment (Wesson \& Gogus, 2005). Mostly, the induction comes in two forms. The first is the formal training programmes and the second is 
informal induction which is often carried out by the workers and managers/supervisors or a combination of both of them (Klein \& Weaver, 2000). These programmes vary depending on the roles, status and the variety of programme activities of the new employees (Wesson \& Gogus, 2005).Induction is often seen as the systematic process of integrating the new employees to the culture, processes, technology and operations of the organization so as to optimize the effect on business outcomes (Snell, 2006). Above all, the principal objective of induction training is to equip the new employees with necessary information and skills so as to cope with the challenges and anxiety that comes in settling into a job or performance (Mestre, Stainer and Stainer (1997). Numerous studies have indicated the importance and significance of induction programmes. Butler (2008), Wells (2005) and Wesson and Gogus (2005) revealed that the level of turnover, absenteeism and satisfaction tends to increase during or after the first few months of the induction. This means that an inadequate and poor induction programme will adversely influence staff attitude. Therefore, it becomes imperative that organizations should put into cognizance different methods of integrating and engaging the new employees to the culture, processes, philosophies, programmes and practices of the organization (Derven, 2008). Researchers indicated that the first few months of a new employee's career are critical in identifying, assessing and evaluating whether he/she will help the organization to achieve competitive advantage, or will fail to do so (Fritz \& Vonderfecht, 2007). Induction facilitates unquantifiable benefits to many organisations such as a reduction in time consumption for new inductees to adjust to organizational culture/core values (Ragsdale \& Mueller, 2005) and to optimize effective working capabilities (Brodie, 2006; Derven, 2008). These benefits are not only restricted to organizations, they also contribute significantly to employees commitment and know how. According to Derven (2008), induction serves as a means of passing the feeling and sense of belongings to the new employees and also such an employee to be decisive in joining the organization without any form of coercion.

A well packaged induction programme involves effective use of proper planning. This plan prepares the new staff in coping with stress and other contingencies like fear of the unknown, inferiority complex, anxiety which are likely to set in during one of the most stressful times in their organisational life (Wanous \& Reichers, 2000). Therefore, to reduce these problems, induction programmes should be made in a way that will make the new staff feel more comfortable and pro active in the organization (Dodds \& Verest, 2002; Ragsdale $\&$ Mueller, 2005). The outcome of every successful induction programmes may significantly bring about job enrichment and acceptable attitude amongst new employees that conforms to the culture and practices of the organization, (Sussman, 2005), which will invariably lead to higher productivity and commitment (D'Aurizio, 2007). Several researchers have also indicated that induction programme could bring about customer satisfaction. This exists when a new staff is tailored and trained with the provision of necessary supports to avoid discouragement during the first few months on employment (D'Aurizio, 2007). Pollitt (2007) study revealed that customer-satisfaction ratings at a major UK energy provider rose from $40 \%$ to $80 \%$ after introducing such an induction programme for all the new employees. Meanwhile, most researchers focused on tangible and cost-related benefits but this study tend to address the emotional benefits for the employees and to encourage retention with positive attitudes towards work. We therefore propose these hypotheses:

$\mathrm{H}_{1}$ : Induction/orientation programmes have positive effect on employees' attitude and organizational effectiveness

$\mathrm{H}_{2}$ : Induction programme has positive impact on employees' intention to stay on the job

\section{Research Methodology}

The empirical data for the study were collected through a well-structured questionnaire, which was prepared and distributed among the respondents in Olabisi Onabanjo University, Ogun State, South-West Nigeria. Purposive and convenience sampling methods were adopted in selecting the participants for this study. The research instrument was divided into two sections, the first tends to obtain the respondent biodata while the second part contains the items regarding the constructs of the subject matter. Descriptive methods of analysis were used to analyse the data. The opinions of the respondents on each question were weighed using simple percentages. This is done so as to ascertain the average opinion of the respondents. A total of 300 copies of questionnaires were administered within the scope of selected location, having sorted the returned questionnaires, only 271 copies of questionnaires representing $90 \%$ were validly used while 29 copies (10\%) were either discarded due to improper filling or unreturned. The study tends to add to the existing study on Human Resource processes and practices in an organisation.

\section{Data Analysis Findings And Discussion}

The data obtained from this study were presented using tables with specifications made on the amount of questionnaire distributed. The results were obtained based on the opinions of the respondents. 
Table 4.1 Socio Demographic Characteristic of the Respondent

\begin{tabular}{|c|c|c|c|}
\hline Variables & Frequency & Percentage & $\begin{array}{l}\text { Cumulative } \\
\text { percentage }\end{array}$ \\
\hline $\begin{array}{ll}\text { SEX } & \\
& \text { Male } \\
& \text { Female } \\
\text { Total } & \\
\end{array}$ & $\begin{array}{l}148 \\
123 \\
\mathbf{2 7 1} \\
\end{array}$ & $\begin{array}{l}54.6 \\
45.4 \\
\mathbf{1 0 0 . 0}\end{array}$ & $\begin{array}{l}54.6 \\
\mathbf{1 0 0 . 0}\end{array}$ \\
\hline $\begin{array}{cc}\text { AGE - GROUP } \\
& 18-25 \\
& 26-35 \\
& 36-45 \\
& 46-55 \\
& 56-\text { above } \\
\text { Total } & \end{array}$ & $\begin{array}{c}16 \\
67 \\
132 \\
44 \\
12 \\
271\end{array}$ & $\begin{array}{c}5.9 \\
24.7 \\
48.7 \\
16.2 \\
4.4 \\
\mathbf{1 0 0 . 0}\end{array}$ & $\begin{array}{l}5.9 \\
30.6 \\
79.3 \\
95.6 \\
\mathbf{1 0 0 . 0}\end{array}$ \\
\hline $\begin{array}{cl}\text { MARITAL STATUS } \\
& \text { Single } \\
& \text { Married } \\
& \text { Divorced } \\
& \text { Widowed } \\
\text { Total } & \\
\end{array}$ & $\begin{array}{c}51 \\
181 \\
22 \\
17 \\
\mathbf{2 7 1} \\
\end{array}$ & $\begin{array}{l}18.8 \\
66.8 \\
8.1 \\
6.3 \\
\mathbf{1 0 0 . 0}\end{array}$ & $\begin{array}{l}18.8 \\
85.6 \\
93.7 \\
\mathbf{1 0 0 . 0}\end{array}$ \\
\hline $\begin{array}{l}\text { EDUCATIONAL } \\
\text { QUALIFICATION } \\
\text { SSCE } \\
\text { OND } \\
\text { B.sc/HND } \\
\text { M.sc/M.BA \& others } \\
\text { Others } \\
\text { Total }\end{array}$ & $\begin{array}{c}16 \\
68 \\
108 \\
65 \\
14 \\
271\end{array}$ & $\begin{array}{l}5.9 \\
25.1 \\
39.9 \\
24.0 \\
5.1 \\
\mathbf{1 0 0 . 0}\end{array}$ & $\begin{array}{l}5.9 \\
31.0 \\
70.9 \\
94.9 \\
\mathbf{1 0 0 . 0}\end{array}$ \\
\hline $\begin{array}{l}\text { LENGTH/YEARS IN } \\
\text { SERVICE } \\
\qquad \begin{array}{l}1-9 \\
10-19 \\
\\
20 \mathrm{yrs} \text { and above }\end{array} \\
\text { Total }\end{array}$ & $\begin{array}{c}97 \\
144 \\
30 \\
271\end{array}$ & $\begin{array}{l}35.8 \\
53.1 \\
11.1 \\
\mathbf{1 0 0 . 0}\end{array}$ & $\begin{array}{l}35.8 \\
88.9 \\
\mathbf{1 0 0 . 0}\end{array}$ \\
\hline
\end{tabular}

Source: Data collected from survey research

Following from Table, $54.6 \%$ of the sample size were male while $45.4 \%$ were female, which implies that the population of male respondent is higher than female. Meanwhile, about $79.4 \%$ (cumulative)of the respondents were within an economically active population. Moreover, $66.8 \%$ of the respondents were married, while $18.8 \%$ were single and 14.4 divorced or separated, though the reason for their present marital status could not be ascertained as at the time of documenting this report. Regarding the years of work experience; $53.1 \%$ of the respondents had worked between 10 and 19 years; while $35.8 \%$ has put in between $1-9$ years; $11.1 \%$ has spent 20 years and above, which makes the respondents authority in responding to questionnaire.

\section{Testing of Hypotheses}

$\mathbf{H}_{1}$ : Induction/orientation programmes have negative effect on employees' attitude and organizational effectiveness

\section{Model Summary}

\begin{tabular}{|l|l|l|l|l|}
\hline Model & R & R Square & $\begin{array}{l}\text { Adjusted R } \\
\text { Square }\end{array}$ & $\begin{array}{l}\text { Std. Error of } \\
\text { the Estimate }\end{array}$ \\
\hline 1 & $.564(a)$ & .318 & .311 & .62225 \\
\hline
\end{tabular}

The model summary table shows how much of the variance in the dependent variable is explained by the model. In this case the $\mathrm{R}$ square is 0.318 if expressed by a percentage will be $31.8 \%$. This means that our model explains $31.8 \%$ of the variance the use of induction and orientation facilitate the value of organizational effectiveness. The adjusted R square shows 0.311 , while the standard error estimate 0.62225 which signifies that the error term was relatively above average.

ANOVA (b)

\begin{tabular}{|ll|l|l|l|l|l|}
\hline Model & & Sum of Squares & Df & Mean Square & F & Sig. \\
\hline 1 & Regression & 38.560 & 2 & 19.280 & 49.794 & .000 \\
& Residual & 82.859 & 214 & .387 & & (a) \\
& Total & $\mathbf{1 2 1 . 4 1 9}$ & $\mathbf{2 1 6}$ & & & \\
\hline
\end{tabular}


The ANOVA table shows the assessment of the statistical significance (sig=0.000), in which the Pvalue is equal to .000 , and less than or equal to 0.05 , therefore we reject the null hypothesis. So we can conclude that induction programmes have positive effect on employees' attitudes and organizational effectiveness.

Coefficients (a)

\begin{tabular}{|c|c|c|c|c|c|}
\hline & \multicolumn{2}{|c|}{$\begin{array}{l}\text { Unstandardized } \\
\text { Coefficients }\end{array}$} & \multirow{2}{*}{$\begin{array}{l}\text { Standardized } \\
\text { Coefficients } \\
\text { Beta } \\
\end{array}$} & \multirow{2}{*}{$\frac{t}{B}$} & \multirow{2}{*}{$\begin{array}{l}\text { Sig. } \\
\text { Std. Error }\end{array}$} \\
\hline & B & Std. Error & & & \\
\hline (Constant) & 1.517 & .285 & & 5.319 & .000 \\
\hline $\begin{array}{l}\text { The development of induction } \\
\text { programmes has led to employees' } \\
\text { competence and organizational } \\
\text { effectiveness }\end{array}$ & .559 & .065 & .513 & 8.540 & .000 \\
\hline $\begin{array}{l}\text { Induction equipped employees with } \\
\text { the necessary skills and good } \\
\text { attitude to work. }\end{array}$ & .085 & .044 & .117 & 1.940 & .054 \\
\hline
\end{tabular}

The co-efficient table shows which variables that were included in the model contributed to the prediction of the dependent variable. The study is interested in comparing the improvement of each independent variable; therefore the Beta values used for the comparison in this table, the largest beta co-efficient is .513 which explains that the development of induction programmes has led to the competence and effectiveness of the employees. The table seeks to explain which of the variables is making a statistically significant unique contribution to the model looking at the Sig column in the table; it reveals that using induction programmes has led to the organizational effectiveness and employees attitude. This view was supported by the works of Mestre, Stainer and Stainer (1997) that induction training is to equip the new employees with necessary information and skills so as to have good attitudes to work and as well cope with the challenges and anxiety that comes in settling into a job or performance. We therefore rejected the null hypothesis and concluded that induction/orientation programmes have negative effect on employees' attitude and organizational effectiveness

$\mathbf{H}_{\mathbf{0 2}}: \mathrm{Ho}_{2}$ : Induction Programme has no effect on employees' intention to stay on the job and attitude to work

Model Summary

\begin{tabular}{|l|l|l|l|l|}
\hline $\begin{array}{l}\text { Mod } \\
\text { el }\end{array}$ & $\mathbf{R}$ & $\begin{array}{l}\text { R } \\
\text { Square }\end{array}$ & $\begin{array}{l}\text { Adjusted R } \\
\text { Square }\end{array}$ & $\begin{array}{l}\text { Std. Error of } \\
\text { the Estimate }\end{array}$ \\
\hline 1 & $.498(\mathrm{a})$ & .248 & .241 & .82032 \\
\hline
\end{tabular}

Following from the above table, $\mathrm{R}$ square is 0.248 if expressed by a percentage will be $24.8 \%$. This means that our model explains $24.8 \%$ of the variance the induction gives value to the employees and enhances their loyalty and commitment. The adjusted R square shows 0.241 , while the standard error estimate 0.82032 which signifies that the error term was relatively above average.

\begin{tabular}{|c|c|c|c|c|c|c|}
\hline \multicolumn{7}{|c|}{ ANOVA (b) } \\
\hline Model & & $\begin{array}{ll}\text { Sum } & \text { of } \\
\text { Squares } & \\
\end{array}$ & Df & $\begin{array}{l}\text { Mean } \\
\text { Square }\end{array}$ & $\mathbf{F}$ & Sig. \\
\hline 1 & $\begin{array}{l}\text { Regression } \\
\text { Residual } \\
\text { Total }\end{array}$ & $\begin{array}{r}47.172 \\
142.660 \\
\mathbf{1 8 9 . 8 3 3}\end{array}$ & $\begin{array}{l}2 \\
212 \\
\mathbf{2 1 4}\end{array}$ & $\begin{array}{l}23.586 \\
.673\end{array}$ & 35.050 & .000 (a) \\
\hline
\end{tabular}

The ANOVA table shows the assessment of the statistical significance $(\mathrm{Sig}=0.000)$, in which the Pvalue is equal to .000 , and less than or equal to 0.05 , therefore we reject the null hypothesis. So we can conclude that induction programmes have positive effect on employees' attitudes and intention to stay on the job.

Coefficients (a)

\begin{tabular}{|c|c|c|c|c|c|}
\hline & \multicolumn{2}{|c|}{$\begin{array}{l}\text { Unstandardized } \\
\text { Coefficients }\end{array}$} & \multirow{2}{*}{$\begin{array}{l}\text { Standardized } \\
\text { Coefficients } \\
\text { Beta } \\
\end{array}$} & \multirow{2}{*}{$\frac{\mathbf{t}}{\mathrm{B}}$} & \multirow{2}{*}{$\begin{array}{l}\text { Sig. } \\
\text { Std. Error }\end{array}$} \\
\hline & $\mathrm{B}$ & Std. Error & & & \\
\hline (Constant) & 1.551 & .362 & & 4.288 & .000 \\
\hline $\begin{array}{l}\text { Experienced gained from induction, } \\
\text { orientation and training are used to } \\
\text { gain entry into other organizations }\end{array}$ & .115 & .078 & .092 & 1.470 & .143 \\
\hline $\begin{array}{l}\text { I feel comfortable and pleasant in } \\
\text { discharging my duties effectively }\end{array}$ & .477 & .065 & .462 & 7.366 & .000 \\
\hline
\end{tabular}


The co-efficient table shows which variables that were included in the model contributed to the prediction of the dependent variable. The study is interested in comparing the improvement of each independent variable; therefore the Beta values used for the comparison in this table, the largest beta co-efficient is .462 which believes experienced gained from induction and training are used to gain entry into other organizations; makes the strongest unique contribution to explaining the dependent variable the use of induction and orientation gives value to the organization when the variance explained by all other variables in the model is controlled. The table seeks to explain which of the variables is making a statistically significant unique contribution to the model looking at the sig column in the table; it reveals that Employee attitude to work is dependent on inadequate induction and training not acquired hence, we reject the null hypothesis. This study also supported the findings of Dodds \& Verest, 2002; Ragsdale \& Mueller, 2005) that induction programmes should be made in a way that will make the new staff feel more comfortable and proactive in the organization.

\section{Conclusion And Recommendations}

The findings revealed that induction significantly influences staff attitude and behaviour towards retention and effectiveness. This means that well packaged induction programme (that has all the relevant information) will positively influence staff attitude. Most (72\%) of the respondents adduced that they had induction programmes and they were psychologically integrated to their work environment. It exposes the new employees to the history and the organization of the institution as well as to the core values/activities, the competitors and their activities. They added that sources of information and available amenities in the company are brought to their attention. However, it was observed that if the induction programmes and system of the organization does not have anything good to transfer, it affects the employees' attitude. The organization believes that induction of new employees with the right training helps in saving time, money and increased productivity. The study supported the findings of Butler (2008), Wells (2005) and Wesson and Gogus (2005) who added that the level of turnover, absenteeism and satisfaction tends to increase during or after the first few months of the induction. This induction programme takes several months and involves different dimensions. $42 \%$ acclaimed that they had induction programme in their first month of employment, $36 \%$ added that they attended after one month while only $22 \%$ were longer-serving employees who were inducted after two months or more of employment. The study also revealed that employees were orientated on what to do, where to do it, when and how to do it through staff handbook, seminars, conferences, on the job training, co-workers meeting, staff forum, etc. Therefore, it becomes imperative and empirical to say that induction programmes for new employees has a significant impact on retention and effectiveness. This supported the inherent assumption that the shortfall in performance is caused by deficiencies in knowledge, skills or attitude. It was recommended that induction programmes should be reviewed and improved upon from time to time and to determine if the induction programme has any effect on the employees' values and attitudes. Irrespective of the approach used, induction policies should ensure fairness to all employees and should help boost employee morale.

\section{References}

[1]. Adenekan A.S (2008) Corporate Ethical Values and Organizational Commitment in Marketing. Lagos, Malthouse Press ltd,.

[2]. Armstrong, M.A (1982) Handbook of Personnel Management Practice. London, Thompson learning

[3]. Armstrong, M.A (2003) A Handbook of Human Resource Management Practice (9th ed.). kundli, replica press ltd.

[4]. Boxall P., Purcell J., Wright P. (2007): The Oxford of Human Resource Management. Britain, oxford university press

[5]. Brodie, J.M. (2006). Getting managers on board. Human Resources Magazine, November, 105-108.

[6]. Butler, K.M. (2008). Getting employees to stay onboard instead of jumping ship. Employee Benefit News, January, 13-14.

[7]. Champoux J.E (2000) Organizational Behaviour: Essential Tenets for a New Millennium. London, south western college publishing

[8]. Cornelius N. (2001) Human Resource Management: A Managerial Perspective (2nd ed.). London, Thompson Learning

[9]. D'Aurizio, P. (2007). Onboarding: Delivering on the promise. Journal of Nursing Economics, 25, $228-229$.

[10]. Derven, M. (2008). Management onboarding. Journal of Training and Development, April, 49-52.

[11]. Dodds, B., \& Verest, M. (2002). E-learning in support of induction training at De Lage Landen. Journal of Industrial and Commercial Training, 34, 70-75.

[12]. Fritz, L.R., \& Vonderfecht, D. (2007). The first 100 days. Journal of Healthcare Executive, November, 8-14.

[13]. Kenrick D.T, Neuberg S.L \& Ciadini R.B (2005). Social Psychology: Unraveling the Mystery (3rd ed.). USA, pearson education inc.,

[14]. Klein, H.J., \& Weaver, N.A. (2000). The Effectiveness of an Organizational Level Orientation Training Program in the Socialization of New hires. Journal of Personnel Psychology, 53, 47-66.

[15]. Kreitner R. \& Kinick A. (2001) Organizational Behaviour. New York, McGrawhill Publications.

[16]. Kearney S 2010. Understanding the Need for Induction Programmes for Beginning Teachers in Independent Catholic Secondary Schools in New South Wales. Paper presented at the Faculty of Education and IERI HDR Conference, University of Wollongong.

[17]. Maxwell T.R., Chonko L.B \& Loe T.W (2001) The Impact of Ethics code familiarity on Managers' behaviour', Journal of Business Ethics, 33 (1), 59-69

[18]. Mestre, M., Stainer, A., \& Stainer, L. (1997). Employee orientation - the Japanese approach. Journal of Employee Relations, 19, 443-456.

[19]. Obasi C.A (2003) Organizational Behaviour: Concepts and Applications. Lagos, Malthouse Press Ltd,

[20]. Ogunbameru O.A (2004) Organizational Dynamics. Ibadan, Spectrum Books Ltd.

[21]. Onasanya S.A.B (1999) Effective Personnel Management and Industrial Relations. Lagos, Centre for Management Development.

[22]. Pollitt, D. (2007). Scottish and Southern Energy slashes staff attrition. Human Resource Management International Digest, 15, 17. 
[23]. Ragsdale, M.A., \& Mueller, J. (2005). Plan, do, study, act model to improve an orientation programme. Journal of Nursing Care Quality, 20, 268-272.

[24]. Snell, A. (2006). Researching On boarding best practice. Strategic HR Review, 5, 32-35.

[25]. Sussman, D. (2005). Getting up to speed. Journal of Training and Development, December, 49-51.

[26]. Wanous, J.P., \& Reichers, A.E. (2000). New employee orientation programs. Journal of Human Resource Management Review, 10, 435-451.

[27]. Wells, S.J. (2005). Diving in. Human Resources Magazine, March, 55-59.

[28]. Wesson, M.J., \& Gogus, C.I. (2005). Shaking Hands with a Computer: An Examination of two Methods of Organizational Newcomer Orientation. Journal of Applied Psychology, 90(5), 1018-1026. 